\title{
An Empirical Study of Modernity in Agricultural Cooperatives in Poland
}

\author{
Małgorzata MATYJA, Magdalena RAJCHELT-ZUBLEWICZ \\ Wrocław University of Economics, Wrocław, Poland \\ \{malgorzata.matyja, magdalena.rajchelt\}@ue.wroc.pl
}

\begin{abstract}
Application of new and contemporary information and communication technologies for rural and agricultural development has been advancing quite rapidly over the last decade. Modern agriculture is a promising pathway to increase the sustainability of farming by increasing farm profitability, reducing manual labour, and reducing environmental impact. The paper discusses an approach to modernity and its influence on profitability in agricultural cooperatives in Poland. Precisely, its purpose is to investigate the links between the income and the level of value and modernity of machinery and equipment, as well as the propensity to monitor and implement technological innovations in Polish agricultural cooperatives. The analysis is based on data collected by survey method from 28 APC operating in the opolskie voivodship - the south-western region of Poland. It reveals a moderate willingness of Polish cooperatives to invest in agricultural machinery and equipment and to monitor and implement technological innovations. Simultaneously, it shows that the cooperative income does not depend on this willingness or on the cooperative members' opinion about modernity of machines used by them. However, it proves the existence of high positive correlation between the value of machinery and equipment and the income in cooperatives.
\end{abstract}

Keywords: Agricultural Cooperatives, Modern Agriculture, Correlation Analysis.

\section{Introduction}

The current trend of automation and data exchange in manufacturing technologies, named as Industry 4.0, has been extending to all areas of human life. This also applies to agriculture. Agricultural production management is entering into a new era where every day farmer's decisions are supported by highly sophisticated Farm Management Information Systems [12]. Application of new and contemporary information and communication technologies for rural and agricultural development has been advancing quite rapidly over the last decade. So-called "smart farming" or "farming 4.0 " seems to meet the requirements of "producing more with less", of rising demand for bigger yields and higher environmental protection. Modern agriculture is a 
promising pathway to increase the sustainability of farming by increasing farm profitability, reducing manual labour, and reducing environmental impact.

In modern agricultural systems farmers, unlikely traditional farmers, believe they have much more central roles and are eager to apply technology and information to control most components of the system [10]. They are aware of the benefits that modern agriculture already offers, including - among others - greater production and income. Particularly modern machinery has been found to contribute to sector efficiency and growth.

According to the data of JRC (The European Commission's in-house science service - the Joint Research Centre), obtained from a survey among 780 farmhouseholds in $6 \mathrm{EU}$ countries, the new agricultural machinery is the top target for investments by farmers in Europe [8]. The research showed that up to $202040.3 \%$ of farmers are planning to invest in machinery, far exceeding the willingness to invest in land $(21.0 \%)$, buildings $(20.3 \%)$ or trainings $(16.2 \%)$. The main benefits expected from new machinery are:

- improved working conditions on the farm,

- cost reduction,

- increase in yields of production,

- increase in quality of production.

Farmers believe investments in new machinery and equipment will respectively contribute $52 \%, 27 \%, 26 \%$ and $24 \%$ to achieve these goals.

Decision about the machinery and equipment in farms are very important and often difficult to take. Though, after land, machinery is the second biggest asset category on most farms [7]. On the other hand, newer equipment may be more efficient, which could help profitability. The recent Ibendahl's research confirm this statement. It turns out that most profitable farms own either the most equipment or the newest equipment. Moreover, they have the highest levels of machinery investments, as well as machinery expenses. However, the most profitable farms have also the lowest levels of machinery costs as a percentage of total costs. Total costs in Ibendahl's research include machinery and land costs. While the most profitable farms have the greatest amounts of machinery, in the bigger picture of total crop expenses, their machinery expenses are actually the lowest. Ibendahl also points out that farmers, attempt to lower taxable income by purchasing more equipment. In his research the most productive farms purchased more machinery to help lower taxes.

Not only individual farmers decide about the size, the form of use (own or rented) and the level of modernity of agricultural machinery and equipment. This refers also to agricultural cooperatives which aim is to provide benefits for members as well as for local community. According to the literature, cooperatives do not only seek to maximize profits, but they also seek to satisfy the interests of their members by increasing the prices of their products as much as possible [5, 6, 13, 14]. However, the access to modern, efficient and work facilitating machines and devices could also be the one these benefits.

A higher level of modernization in cooperatives is related to a higher value of fixed assets, including machinery. The studies on American agricultural cooperatives show 
the positive link between the value of assets with cooperatives' performance [2, 9]. Also, the empirical evidence obtained in the study in Spain provides information about the positive impact of size, measured by total assets among others, on the efficiency of agricultural cooperatives [1]. Therefore, the advantages associated with greater size - economies of scale, greater negotiating power and ease of access to different resources, such as technological ones, imply a competitive advantage that translates into increased performance.

But how do the cooperatives deal with providing funds for their modernization? It turns out, that most agricultural cooperatives have moved with much of the rest agriculture down a trajectory dependent on large capital-intensive production units and technology, with heavy reliance on external sources of energy and credit [4]. The recent report of support for farmers' cooperatives confirms using external funds to modernize buildings and invest in new facilities and equipment by for example German or Spanish cooperatives [3]. Also in Bulgarian case the support measures enabled cooperative leaders to modernize the equipment and machinery and, in this way, have not only stabilized the structure of agricultural production cooperatives but also the villages' economy and the safety net for the poor and elderly people. Thus, modernization in cooperatives could affect not only profits for cooperatives, but it also benefits to the local community.

In the light of such tangible and intangible results of modernization in agricultural production this paper discusses an approach to modernity and its influence on profitability in agricultural cooperatives in Poland. Precisely, its purpose is to investigate the links between the income and the level of value and modernity of machinery and equipment, as well as the propensity to monitor and implement technological innovations in Polish agricultural cooperatives.

\section{Methodology of research}

The analysis is based on data collected by survey method from 28 agricultural production cooperatives (APC) operating in the opolskie voivodship - the southwestern region of Poland. The research was conducted in 2011. The survey was sent to all of the operating cooperatives in this region (approximately 100). However, the responses were obtained only from the 33 APC, from which additionally five was eliminated due to incompleteness of data.

All surveyed ACP conduct crop production, especially the cultivation of wheat, canola, barley and corn. More than half of them in the analyzed period also led livestock production, mainly pigs. The basic characteristics of the research sample is presented in Table 1.

Based on the respondent's opinion the survey allowed to determine in each cooperative the following factors:

- the level of modernity of machinery and equipment,

- the emphasis on tracking new technologies,

- striving for implementation of product and technological innovation. 
Table 1. Basic characteristics of the research sample.

\begin{tabular}{lcccccc}
\hline Item & $\begin{array}{l}\text { Total } \\
\text { income* } \\
\text { (PLN) }\end{array}$ & $\begin{array}{l}\text { Assets } \\
\text { (PLN) }\end{array}$ & $\begin{array}{l}\text { Value of } \\
\text { machinery } \\
\text { (PLN) }\end{array}$ & $\begin{array}{l}\text { Agricultural } \\
\text { land (ha) }\end{array}$ & $\begin{array}{l}\text { No. of } \\
\text { members }\end{array}$ & $\begin{array}{l}\text { No. of } \\
\text { employees }\end{array}$ \\
\hline min & 201650 & 1142333 & 41333 & 98 & 5 & 6 \\
average & 824141 & 5231605 & 887987 & 616 & 19 & 20 \\
$\max$ & 4068963 & 24075093 & 3763486 & 3500 & 65 & 72 \\
\hline
\end{tabular}

* net profit + membership fee

The analysis should bring the answer to the question if the above factors influence income in APC. A correlation analysis, which shows the degree to which two variables are related [15], was used to verify this influence. The hypotheses were the following:

- null hypothesis H0: no relation between variables,

- alternative hypothesis H1: the occurrence of the relation between variables.

The process of verifying hypotheses was to reject the null hypothesis in favour of the adoption of the alternative hypothesis, taking into account the level of significance $\alpha=0.05$. Analysis of relationship was based mainly on the calculation of the values of the selected coefficients and their interpretation [11].

In case of quantitative variables (income and value of machinery and transport equipment) the Kendall's $\tau$ coefficient was calculated. This indicator determines the correlation between the variables in the characteristics measured by at least an ordinal scale. It accepts values from -1 to 1 showing not only the strength of correlation, but also its direction.

Due to the fact that some of analyzed factors are the qualitative variables, the chisquare test was also used. In examining the relationship between variables using this parameter, it is necessary to indicate the significance level $\mathrm{p}$, which determines the probability of the correlation. If the investigated group includes not less than 20 and no more than 40 units, and any of the expected numbers is less than five, the chisquare with Yates correction shall apply. To evaluate how strong is the possible correlation, the $\Phi$ Yule's coefficient was also determined.

Moreover, the above coefficients require the division of the analyzed units into two groups that differ from each other. This relates in particular such quantitative variables as income and value of machinery and transport equipment. The formula of the division was the following:

- group A - units with income below the average,

- group B - units with income above the average,

- group X - units with value of machinery and transport equipment below the average,

- group Y- units with value of machinery and transport equipment above the average. 


\section{Research results}

It turns out, that cooperatives are constantly trying to modernize their machine park (see Fig. 1.). In the last three years preceding the survey almost all of them made the purchase of equipment, more than half expanded their farmland and nearly $40 \%$ modernized machines and buildings.

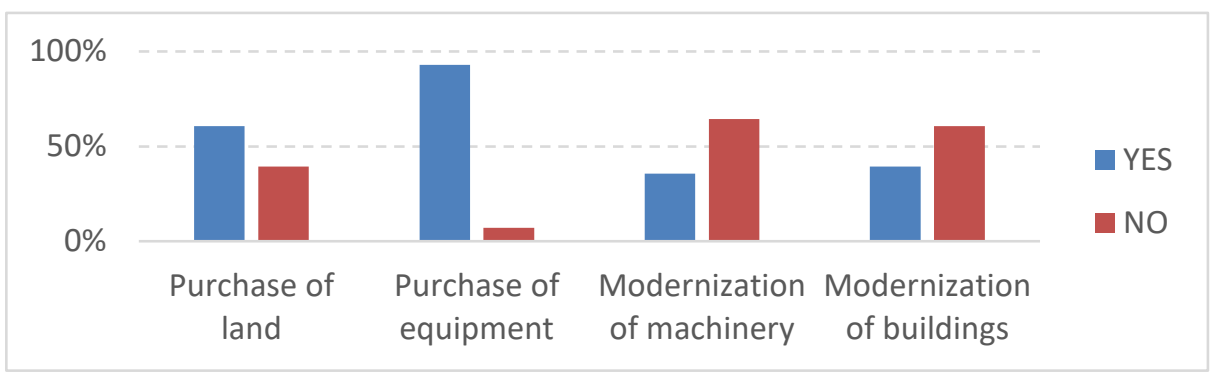

Fig. 1. Investment over the past three years in surveyed cooperatives.

Respondents have a positive opinion about the technical condition of fixed assets (see Fig. 2.). The vast majority (68\%) defines it as "medium", a quarter as "strong" and $4 \%$ as "leading". Also, only $4 \%$ of them claims about the level of modern their machinery and equipment.

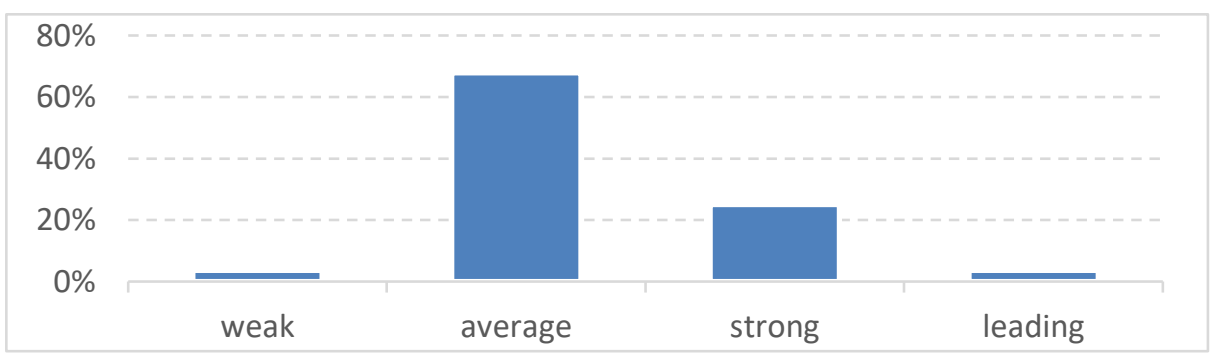

Fig. 2. The level of modernity of machinery and equipment in surveyed cooperatives.

Although APC seem to be interested in monitoring technological innovation (96\% in total), only $19 \%$ of them declare a strong willingness to implement them in their work. Slightly more than half of respondents "rather" try to follow and implement modern production methods. On the other hand, for a quarter of respondents $(27 \%$ in total), innovation does not have much significance. The data presented in Fig. 3. reflect the APC approach to tracking and implementing innovative solutions in their agriculture production. 


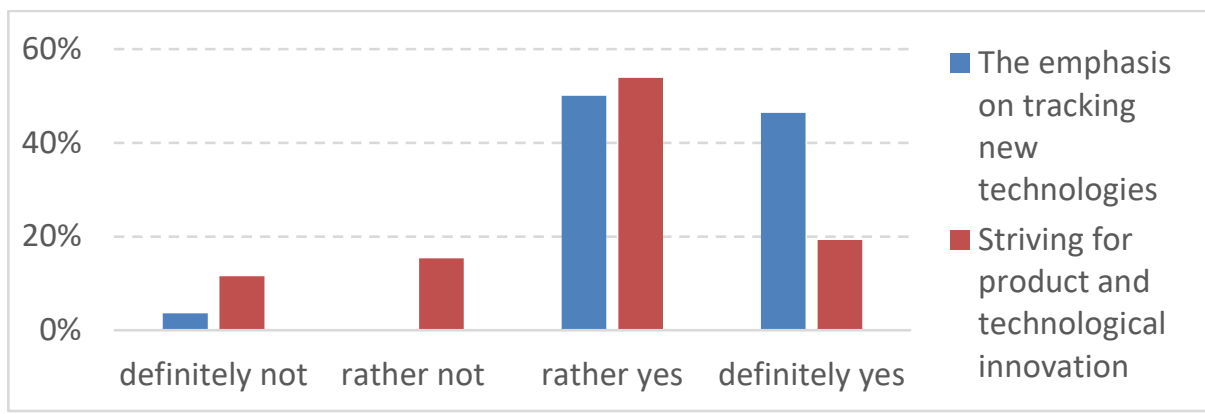

Fig. 3. Respondents' answers to questions on the propensity to monitor and introduce technological innovations in agricultural production.

When analyzing the impact of the above factors on income of cooperatives, the results seem not to be so fascinating (see Table 2.). It turns out, that neither the level of modernity of machinery and equipment, nor the propensity of monitoring or implementing technological innovations influences the profitability of cooperatives. In these cases, the $\mathrm{p}$ value over $\alpha=0.05$ indicates that the relationship is not statistically significant. However, we can observe the positive link between income and value of machinery and transport equipment. This is confirmed by the Kendall's $\tau$ coefficient, chi-square test and $\Phi$ Yule's. Moreover, the correlation between these variables is relatively high $(\tau=0.51)$, which shows that the value of machinery and transport equipment essentially influences the income in cooperatives. Besides, the positive relation indicates that the value of one variable increases with the increase of the other. So, one can say that the more equipment the cooperative has or the more expensive it is, the more it earns.

Table 2. The correlation coefficients of income and selected factors in surveyed cooperatives.

\begin{tabular}{l|c|c|c|c|c|}
\hline \multicolumn{1}{c|}{ Item } & $\begin{array}{c}\text { Kendall's } \\
\tau\end{array}$ & $\chi^{2}$ & $\begin{array}{c}\text { Yates's } \\
\text { correction } \\
\text { of } \chi^{2}\end{array}$ & $\begin{array}{c}\Phi \\
\text { Yule's }\end{array}$ & \multicolumn{2}{|c|}{ Graphs } \\
\hline $\begin{array}{l}\text { Value of } \\
\text { machinery } \\
\text { and } \\
\text { transport } \\
\text { equipment }\end{array}$ & $\begin{array}{c}0.51, \\
\mathrm{p}<0.05\end{array}$ & $\begin{array}{c}4.73, \\
\mathrm{p}=0.03\end{array}$ & $\begin{array}{c}3.07, \\
\mathrm{p}=0.08\end{array}$ & -0.41 & \\
\hline
\end{tabular}




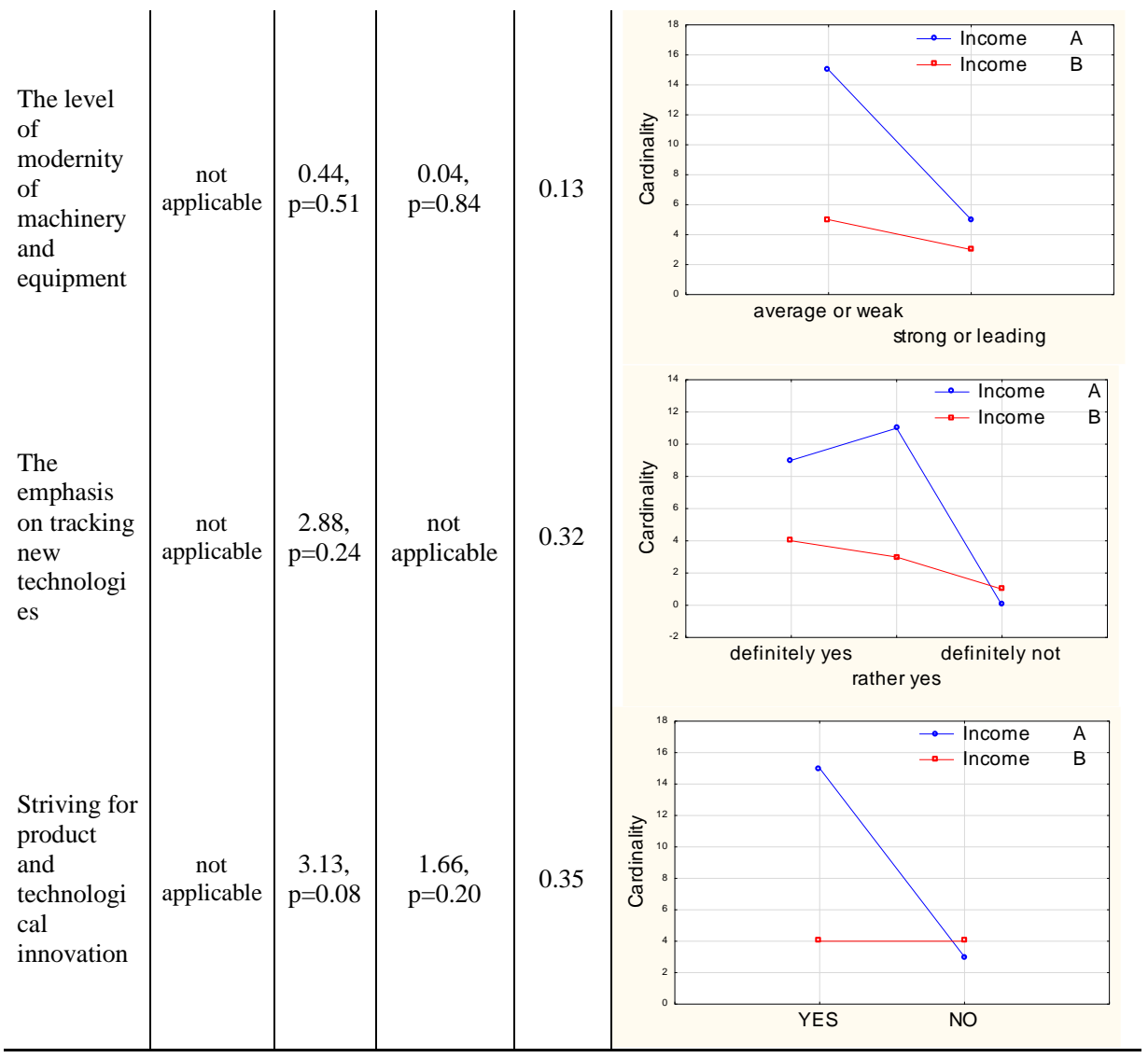

\section{Discussion}

The analysis revealed a moderate willingness of Polish cooperatives to invest in agricultural machinery and equipment and to monitor and implement technological innovations. Simultaneously, it showed that the cooperative income did not depend on this willingness or on the cooperative members' opinion about modernity of machines used by them. However, it proved the existence of high positive correlation between the value of machinery and equipment and the income in cooperatives. When cooperatives invest in equipment increasing its value, they decrease taxes and in the same time increase net income. This explains the correlation and confirms the abovementioned Ibendahl's findings.

On the other hand, higher value means more expensive machinery and/or newest machinery. This in turn goes hand in hand with higher depreciation costs. The greater depreciation is, the lower should be the income. Ibendahl also found this unexpected that the most profitable farms have the greatest depreciation. He explains that this is due to the fact that the most profitable farms own either the most equipment or the 
newest equipment. Moreover, the benefits of having newer equipment can simply outweigh the cost of depreciation.

\section{Conclusion}

Much has been written lately on modern agriculture [4]. Considerable focus is given on describing its various characteristics, such as: international competition, global sourcing and selling, industrialization, differentiation of products, food safety, environment protection, high technology, biotechnology, information technology. To be competitive cooperatives must keep up with the progress in agriculture and they have to meet increasingly stringent requirements related to agricultural production.

Continuous technical and technological progress in agriculture in general leads to the possibility of increasing the efficiency of farming. However, it is not enough to be just a passive observer of the situation around. Cooperatives, in order to improve their efficiency, should try their best to use modern, more efficient machinery and equipment as well as methods of agricultural production.

Although the research presented in this article provides a view on the modernity level in cooperatives, one has to remember that the findings were obtained only from 28 entities. This represents only $4 \%$ of a total population of Polish APC and is concentrated on only one region of Poland, where the agriculture is well-developed. Therefore, the research should be extended to ensure the representativeness of the data. Moreover, the respondents' opinion on the level of modernity and their declarations of propensity to monitor and implementing technological innovations showed no relation to the income of APC. It is suggested to replace these qualitative variables with quantitative ones to allow the use of more powerful statistical tests. As it was mentioned in the article, technological progress in agricultural cooperatives is an important issue and therefore it should be continued in both research and practice.

\section{References}

1. Arcas, N., García, D., Guzmán, I.: Effect of Size on Performance of Spanish Agricultural Cooperatives. Outlook on Agriculture 40(3), 201-206 (2011)

2. Barton, D. G., Schroeder, T. C., and Featherstone, A. M.: Evaluating the Feasibility of Local Cooperative Consolidations: a Case Study. Agribusiness 9(3), 281-294 (1993).

3. Bijman, J., Iliopoulos, C., Poppe, K., Gijselinckx, C., Hagedorn, K., Hanisch, M., Hendrikse, G.W.J., Kuhl, R., Ollila, P., Pyykkonen, P., Sangen, G.: Support for Farmer's Cooperatives. EC, Brussels (2012), p. 50, 97.

4. Gray, T. W.: High Modernity, New Agriculture, and Agricultural Cooperatives: A Comment. Journal of Cooperatives 15, 63-73 (2000).

5. Guzmán, I., Arcas, N.: The usefulness of accounting information in the measurement of technical efficiency in agricultural cooperatives. Annals of Public and Cooperative Economics 79 (1), 107-131 (2008).

6. Hernandez-Espallardo, M., Arcas-Lario, N., Marcos-Matás, G.: Farmers' satisfaction and intention to continue membership in agricultural marketing cooperatives: neoclassical 
versus transaction cost considerations. European Review of Agricultural Economics 40(2), 239-260 (2013).

7. Ibendhal, G.: The Effects of Machinery Costs on Net Farm Income. Journal of ASFMRA $1,113-123$ (2015).

8. JRC: European farmers' intentions to invest in 2014-2020, http://publications.jrc.ec.europa.eu/repository/bitstream/JRC90441/ipts\%20jrc\%2090441\% 20\%28online\%29\%20final.pdf, last accessed 2017/11/03.

9. Lerman, Z., and Parliament, C.: Size and Industry Effects in the Performance of Agricultural Cooperatives. European Review of Agricultural Economics 6(1), 15-29 (1991).

10. Motes, W. C.: Modern Agriculture and Its Benefits - Trends, Implications and Outlook. Global Harvest Initiative, Washington (2010), p. 13, 18, 31.

11. Ostasiewicz, W. (Ed.).: Statistical methods of data analysis. Wroclaw University of Economics, Wrocław (1999), pp. 66-82. [In Polish]

12. Paraforos, D. E., Vassiliadis, V., Kortenbruk, D., Stamkopoulos, K., Ziogas, V., Sapounas, A. A., Griepentrog, H.: A Farm Management Information System Using Future Internet Technologies. IFAC-PapersOnLine 49-16, 324 (2016).

13. Soboh, R., Lansink, A., Giensen, G., Van Djik, G.: Performance measurement of the agricultural marketing cooperatives: The gap between theory and practice. Review of Agricultural Economics 31(3), 446-469 (2009).

14. Soboh, R., Lansink, A., Van Dijk, G.: Efficiency of cooperatives and investor-owned firms revisited. Journal of Agricultural Economics 63 (1), 142-157 (2012).

15. Stanisz, A.: Approachable statistics course using STATISTICA PL on the examples of medicine. Statsoft Poland, Cracow (2006), p. 130. [In Polish] 